INTENSIF, Vol.3 No.1 February 2019

ISSN: 2580-409X (Print) / 2549-6824 (Online)

Website: http://ojs.unpkediri.ac.id/index.php/intensif

\title{
Pengembangan Aplikasi Manajemen Rekrutmen Karyawan Menggunakan Metode Profile Matching
}

Development of Employee Recruitment Management Applications using Profile Matching Method

\author{
${ }^{1}$ Raphael Christopher, ${ }^{2}$ Hery, ${ }^{3}$ Andree E. Widjaja, ${ }^{4}$ Suryasari \\ ${ }^{1,2,3,4}$ Sistem Informasi, Universitas Pelita Harapan \\ ${ }^{1,2,3}$ Tangerang, Indonesia \\ E-mail: ${ }^{1}$ raphael.christ@yahoo.com, ${ }^{2}$ hery.fik@uph.edu, ${ }^{3}$ andree.widjaja@uph.edu, \\ ${ }^{4}$ suryasari.fik@uph.edu
}

\begin{abstract}
Abstrak - Sumber Daya Manusia (SDM) adalah salah satu aspek yang penting dalam perusahaan, karena SDM akan mengelola aspek-aspek lain seperti teknologi, sumber daya dan modal, Hal ini menyebabkan proses perekrutan dan pengalokasian pelatihan merupakan hal penting di perusahaan. Human Resource Departement (HRD) bertanggung jawab untuk merekrut karyawan baru dan mengembangkan program-program pelatihan untuk melengkapi karyawan atau calon karyawan. Proses perekrutan karyawan pada dasarnya dibagi menjadi tiga tahapan, yaitu: pengumpulan CV (Curriculum Vittae), psikotes dan wawancara. Pada PT. XYZ Proses perekrutan masih dilakukan secara manual, oleh karena itu dibutuhkan suatu sistem informasi yang dapat menunjang proses pengambilan keputusan pada proses perekrutan karyawan yang dapat menganalisis pelatihan yang sesuai untuk calon karyawan. Pengembangan sistem informasi perekrutan karyawan dan pengalokasian pelatihan calon karyawan menggunakan metodologi pengembangan System Development Life Cycle (SDLC) dengan menggunakan prototyping. Untuk sistem pengalokasian pelatihan karyawan digunakan metode profile matching. Hasil akhir penelitian ini adalah suatu sistem informasi yang dapat membantu HRD PT. XYZ dalam proses perekrutan dan pengalokasian pelatihan.
\end{abstract}

Kata Kunci- HRIS, Profile Matching, SDLC, Prototyping, UML

Abstract - Human Resources (HR) is one of the important aspects in the company, because it will manage many aspects such as technology, resources, and capital, therefore the process of hiring and allocating training is important in the company. Human Resource Departement (HRD) is responsible for recruiting new employees and developing training programs to equip employees or prospective employees. The Recruitment process consist of three steps: CV gathering, psychotest work, and interview). In PT. XYZ recruitment process is done manually,Therefore an application is required that can support the decision-making process in the employee recruitment process that can analyze the appropriate training for prospective employees. Employee recruitment applications development and allocation of employee training using the System Development Life Cycle (SDLC) system development methodology. For employee training allocation system with profile matching method. The Final result from this research is an application that could support HRD in recruitment process and training allocation.

Keywords—HRIS, Profile Matching, SDLC, Prototyping, UML

INTENSIF: Jurnal Ilmiah Penelitian dan Penerapan Teknologi Sistem Informasi 
INTENSIF, Vol.3 No.1 February 2019

ISSN: 2580-409X (Print) / 2549-6824 (Online)

Website: http://ojs.unpkediri.ac.id/index.php/intensif

\section{PENDAHULUAN}

Sumber Daya Manusia (SDM) adalah salah satu aspek penting dalam perusahaan, yang akan mengelola aspek-aspek lainnya seperti teknologi, sumber daya dan modal [1]. Human Resource Department (HRD) merupakan departemen yang memiliki peran penting dalam menentukan SDM berkualitas pada saat perekrutan dan mengatur dalam proses pengembangan karyawan melalui program pelatihan yang terencana dan terarah. Penempatan karyawan yang sesuai dengan kriteria yang diberikan perusahaan, akan mampu meningkatkan motivasi, produktivitas dan kepuasan kerja dari karyawan itu sendiri. [2]. Calon karyawan yang berhasil melewati tahap perekrutan akan mengikuti sebuah pelatihan yang dirancang untuk mengembangkan dan meningkatkan kemampuan yang ada dalam diri calon karyawan.

PT. XYZ merupakan suatu perusahaan yang bergerak dalam bidang produksi flexible packaging, dengan jumlah karyawan lebih dari 1.300 orang, dengan berkembangnya PT. XYZ, maka dibutuhkan sumber daya manusia yang berkualitas. Proses perekrutan (pengumpulan CV, pengerjaan psikotes, dan wawancara) dan pengalokasian pelatihan calon karyawan masih dilakukan secara manual, hal tersebut dinilai akan lebih efektif dan efisien apabila dilakukan dengan bantuan sistem informasi, khususnya suatu sistem informasi yang dapat membantu dalam mengalokasikan pelatihan yang diperlukan oleh calon karyawan. Proses pengalokasian Pelatihan calon karyawan akan dilakukan dengan metode profile matching.

Beberapa penelitian terdahulu yang relevan dengan penelitian ini, seperti penelitian dari Sucipto, “Analisa Hasil Rekomendasi Pembimbing Menggunakan Multi-Attribute Dengan Metode Weighted Product"[3], Sunarti dan Jenie Sundari, "Perbandingan Metode SAW dan Profile Matching Pada Pemilihan Rumah Tinggal”[4], dan Adhika Pramita Widyassari, "Aplikasi Sistem Pendukung Keputusan Penilaian Kinerja Karyawan untuk Kenaikan Gaji pada PT AAA"[5].

\section{METODE PENELITIAN}

\section{A. Human Resource Management (HRM)}

Human Resource Management (HRM) adalah suatu studi dari ilmu manajemen yang berfokus pada bagaimana menarik, mempekerjakan, melatih, memotivasi dan memelihara karyawan [6]. Karyawan yang kuat dapat menjadi sumber keunggulan kompetitif di lingkungan global yang berubah dengan pesat. Aktivitas HRM yang akan dibahas dalam penelitian ini adalah Human Resource Information Systems (HRIS). 
INTENSIF, Vol.3 No.1 February 2019

ISSN: 2580-409X (Print) / 2549-6824 (Online)

Website: http://ojs.unpkediri.ac.id/index.php/intensif

\section{B. Human Resource Information Systems (HRIS)}

Human Resource Information Systems (HRIS) adalah suatu sistem komputerisasi yang membantu dalam mengelola HRM [6]. HRIS membantu memfasilitasi proses HRM baik dalam merencanakan, membuat keputusan dan mengevaluasi hasil pekerjaan.

\section{Rekrutmen}

Karyawan merupakan sumber daya manusia yang berperan dalam menggerakan atau mengelola sumber daya lain yang ada di dalam organisasi, sehingga organisasi harus dapat menggunakan sumber daya manusia yang ada secara efektif dan efisien sesuai dengan kebutuhan organisasi [7]. Rekrutmen merupakan suatu proses pencarian tenaga kerja yang dilakukan oleh perusahaan dengan tujuan untuk menemukan, mengidentifikasi dan menarik calon karyawan untuk dipekerjakan oleh perusahaan [8]. Perekrutan terdiri dari beberapa langkah seperti berikut:

1) Proses mendapatkan pelamar.

2) Proses penyaringan pelamar.

3) Proses penempatan.

\section{Sistem Pengambilan Keputusan}

Sistem Pengambilan Keputusan merupakan sebuah sistem informasi berbasis komputer yang dapat menghasilkan berbagi alternatif keputusan, yang dapat digunakan untuk membantu manajemen dalam menyelesaikan berbagi permasalahan baik yang terstruktur maupun tidak terstruktur dengan menggunakan data dan model [9].

\section{E. Profile Matching}

Profile Matching merupakan salah satu metode yang digunakan untuk pengambilan keputusan di dalam manajemen sumber daya manusia untuk mencocokan suatu jabatan dengan kualifikasi yang telah ditetapkan sebelumnya [10]. Cara kerja dari profile matching dengan membandingkan antara nilai data aktual dari sebuah barang yang diharapkan memiliki nilai yang ideal [11]. Berikut adalah beberapa tahapan dan perumusan perhitungan dengan metode profile matching:

1. Menentukan aspek dan sub aspek penilaian

Pada tahap ini akan ditentukan aspek-aspek apa saja yang akan dinilai.

2. Perhitungan pemetaan GAP

Pada tahap ini akan ditentukan nilai dari suatu GAP, dimana GAP tersebut didapat berdasarkan rumus:

$$
\text { GAP = Nilai aktual aspek }- \text { Nilai aspek yang diharapkan }
$$

3. Pembobotan

Setelah diperoleh nilai dari GAP, masing-masing aspek diberikan bobot yang sudah ditentukan.

a. Perhitungan dan pengelompokan core dan secondary factor

INTENSIF: Jurnal Ilmiah Penelitian dan Penerapan Teknologi Sistem Informasi 
INTENSIF, Vol.3 No.1 February 2019

ISSN: 2580-409X (Print) / 2549-6824 (Online)

Website: http://ojs.unpkediri.ac.id/index.php/intensif

Setiap aspek dikelopokan menjadi dua kelompok, core factor dan secondary factor, perhitungan core factor dapat dilakukan dengan rumus:

$\mathrm{NCF}=\Sigma \mathrm{NC} / \Sigma \mathrm{IC}$

Keterangan:

$\mathrm{NCF}=$ Nilai rata-rata core factor

$\Sigma \mathrm{NC}=$ Jumlah total nilai core factor

$\Sigma \mathrm{IC}=$ Jumlah item core factor

Sedangkan untuk perhitungan secondary factor dapat dilakukan dengan rumus:

$\mathbf{N S F}=\boldsymbol{\Sigma N S} / \mathbf{\Sigma I S}$

Keterangan:

$\mathrm{NSF}=$ Nilai rata-rata secondary factor

$\Sigma \mathrm{NS}=$ Jumlah total nilai secondary factor

$\Sigma \mathrm{IS}=$ Jumlah item secondary factor

b. Perhitungan nilai total

Berdasarkan hasil perhitungan setiap aspek di atas, maka akan dihitung nilai total berdasarkan presentasi dari core dan secondary factor, yang dapat dihitung dengan rumus:

$$
\mathrm{NT}=(\mathrm{X}) \% \mathrm{NCF}+(\mathbf{X}) \% \mathrm{NSF}
$$

Keterangan:

$\mathrm{NT}=$ Nilai total

NCF $=$ Nilai rata-rata core factor

$\mathrm{NSF}=$ Nilai rata-rata secondary factor

$(\mathrm{X}) \% \quad$ = Nilai persen yang dimasukan

4. System Development Life Cycle (SDLC)

System Development Life Cycle (SDLC) merupakan suatu proses untuk memahami bagaimana sistem informasi dapat mendukung akan kebutuhan bisnis melalui serangkaian proses perancangan suatu sistem [12]. SDLC terdiri dari empat tahap, antara lain: perencanaan (planning), analisis (analysis), desain (design) dan implementasi (implementation). Pengembangan rekayasa sistem informasi (system development) dan atau perangkat lunak (software engineering) dapat berarti menyusun sistem atau perangkat lunak yang benar - benar baru atau yang lebih sering terjadi menyempurnakan yang sebelumnya [13][14].

Metode pengembangan sistem yang digunakan adalah dengan menggunakan metode SDLC, dimana tujuannya adalah untuk menggambarkan tahapan-tahapan pengembangan sistem yang dimulai dengan tahap perencanaan, analisis, desain dan implementasi [12]. Metode yang digunakan untuk pengambilan keputusan adalah dengan menggunakan metode profile matching. Profile matching adalah metode sistem penunjang keputusan yang didasarkan pada 
INTENSIF, Vol.3 No.1 February 2019

ISSN: 2580-409X (Print) / 2549-6824 (Online)

Website: http://ojs.unpkediri.ac.id/index.php/intensif

pengasumsian adanya suatu nilai variabel yang ideal yang harus dipenuhi oleh subjek [15]. Proses psikotes akan dilakukan dengan menggunakan metode tes DISC. DISC adalah suatu alat ukur kepribadian yang didasarkan pada empat tipe kepribadian manusia (Dominance, Influence, Steadiness, Compliance)[16]. Pengembangan sistem informasi ini digunakan bahasa pemrograman HTML, CSS, PHP dan JavaScript dan untuk basis data menggunakan MySQL.

Tahapan pertama yang dilakukan oleh pelamar adalah dengan mengumpulkan CV (Curriculum Vitae). Pelamar akan mengisi data pada website PT.XYZ. Pelamar yang berhasil melewati tahapan ini maka pelamar akan mengerjakan psikotes, dan sistem akan mengecek hasil psikotes, berdasakan hasil psikotes, sistem akan mengatur pengalokasian pelatihan bagi calon karyawan. Pelamar yang berhasil lulus pada psikotes, maka pelamar akan melakukan wawancara dengan pihak HRD dan user, hasil akhir dari rekrutman akan ditentukan oleh HRD dan user. Diagram alur dapat dilihat pada gambar 1.

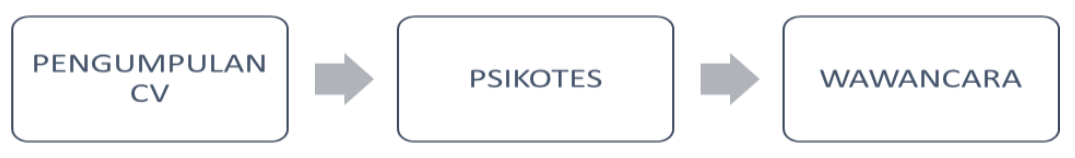

Gambar 1. PROSES REKRUTMEN PT. XYZ

\section{HASIL DAN PEMBAHASAN}

A. Tahap Analisis

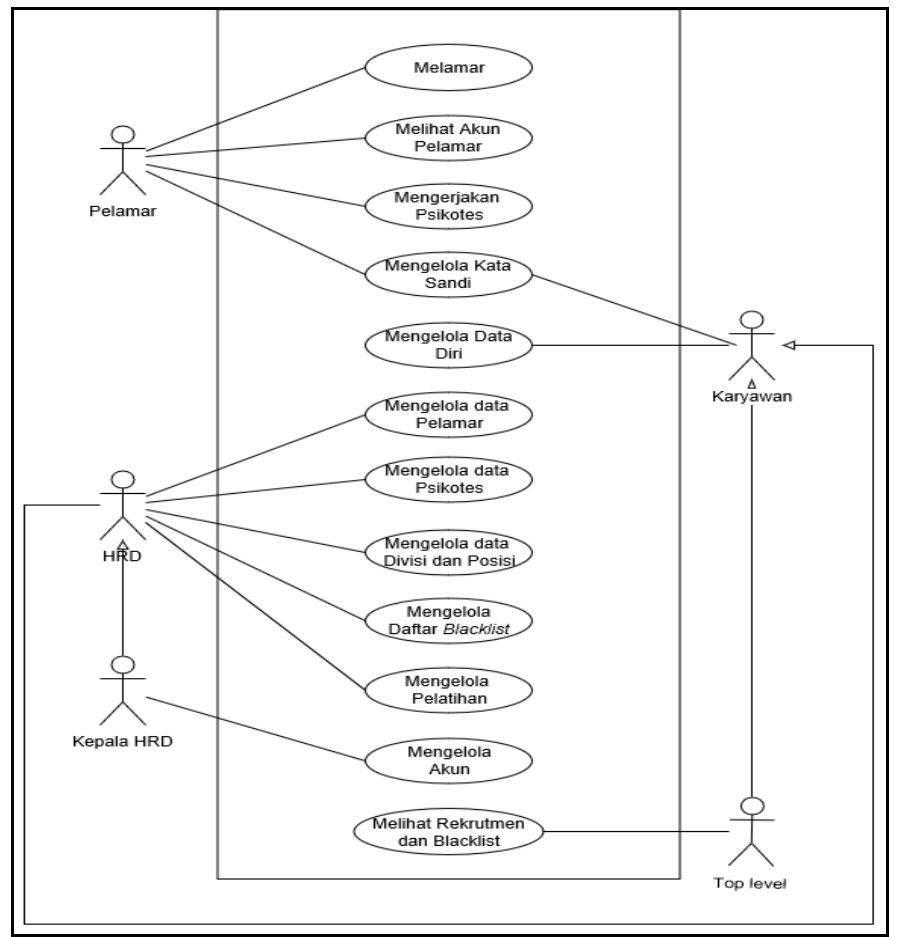

Gambar 2. USE CASE DIAGRAM: PENGEMBANGAN APLIKASI

INTENSIF: Jurnal Ilmiah Penelitian dan Penerapan Teknologi Sistem Informasi 
INTENSIF, Vol.3 No.1 February 2019

ISSN: 2580-409X (Print) / 2549-6824 (Online)

Website: http://ojs.unpkediri.ac.id/index.php/intensif

Pada tahapan ini dirancang Use case diagam sistem informasi perekrutan dan pengalokasian pelatihan calon karyawan dapat dilihat pada gambar 2. Hasil dari Usecase dikembangkan menjadi Class diagram. Class Diagram sistem informasi perekrutan dan pengalokasian pelatihan calon karyawan dapat dilihat pada gambar 3. Class diagram dirancang sesuai dengan use case diagram pada gambar 1 yang terdiri dari 5 aktor yaitu Pelamar, Karyawan, HRD, Kepala HRD dan Top Level.

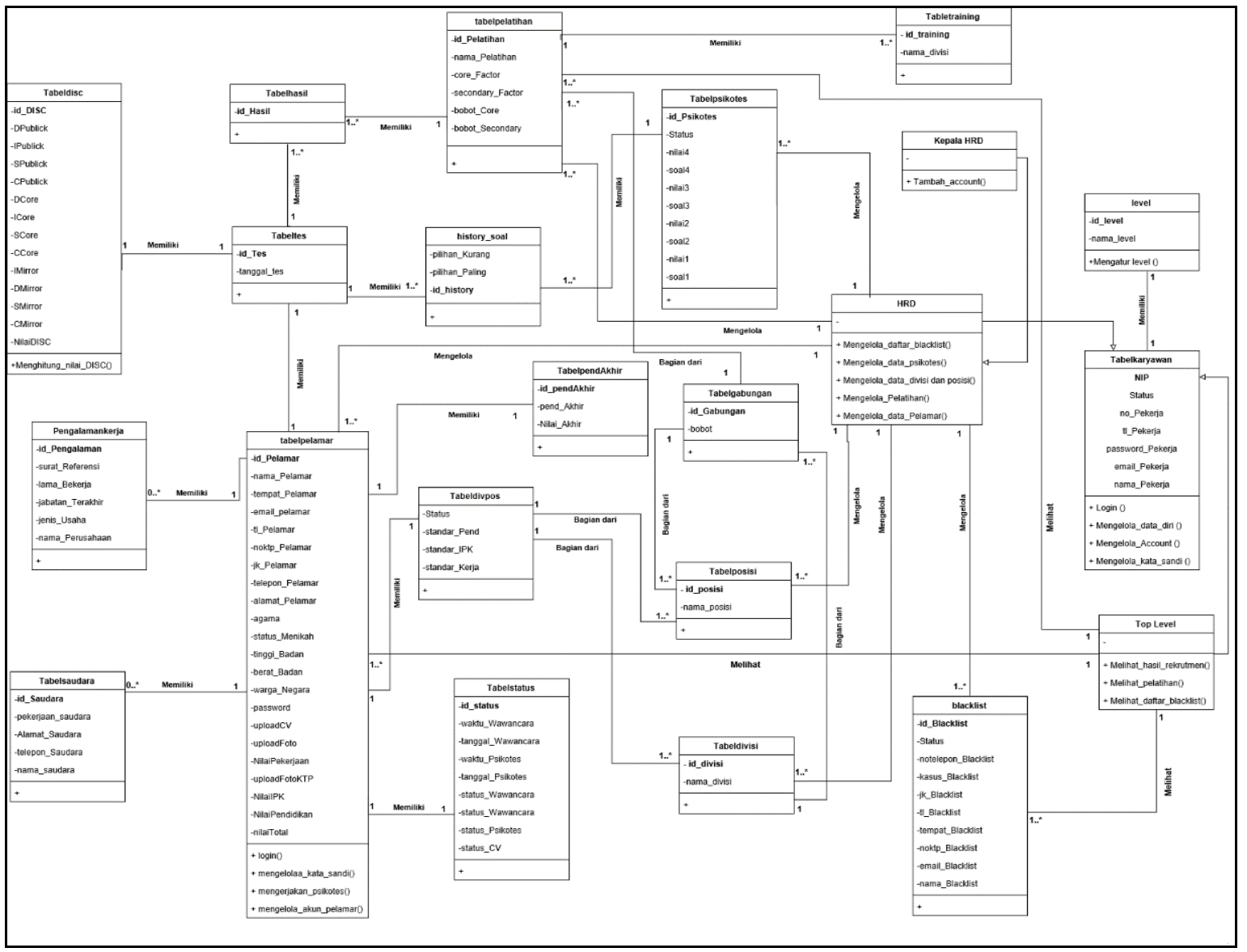

Gambar 3. CLASS DIAGRAM PENGEMBANGAN

\section{B. Tahap Perancangan}

Pada penelitian ini metode profile matching hanya digunakan sampai tahap ketiga, dikarenakan metode profile matching digunakan untuk membantu HRD dalam mengalokasikan pelatihan bagi calon karyawan.

Contoh:

Rayzel melamar pada posisi kasir di divisi finance accounting, setelah mengikuti tahapan rekrutmen Rayzel berhasil melewati tahap penyeleksian CV, maka Rayzel melanjutkan ke tahap psikotes yang ditunjukan pada tabel 1 . 
INTENSIF, Vol.3 No.1 February 2019

ISSN: 2580-409X (Print) / 2549-6824 (Online)

Website: http://ojs.unpkediri.ac.id/index.php/intensif

Tabel 1. HASIL PSIKOTES RAYZEL

\begin{tabular}{ccc}
\hline \hline Variabel & Paling & Kurang \\
\hline D & 3 & 6 \\
\hline I & 1 & 8 \\
\hline S & 8 & 3 \\
\hline C & 9 & 4 \\
\hline$*$ & 3 & 3 \\
\hline Total & 24 & 24
\end{tabular}

Sistem melakukan pengolahan data dari hasil psikotes yang ditunjukan pada tabel 2 .

Tabel 2. HASIL DISC RAYZEL

\begin{tabular}{cccccc}
\hline \hline & D & I & S & C & $*$ \\
\hline Most & 3 & 1 & 8 & 9 & 3 \\
\hline Least & 6 & 8 & 3 & 4 & 3 \\
\hline Change & -3 & -7 & 5 & 5 & \\
\hline
\end{tabular}

Hal yang harus dilakukan pertama kali adalah menghitung jumlah D, I, S, C total dengan cara sebagai berikut:

$$
\begin{aligned}
\mathrm{D}_{\text {Total }}= & \left(\mathrm{D}_{\text {Most }}+\mathrm{D}_{\text {Least }}+\mathrm{D}_{\text {Change }}\right) / 3 \\
& =(3+6-3) / 3=2=2 \\
\mathrm{I}_{\text {Total }}= & \left(\mathrm{I}_{\text {Most }}+\mathrm{I}_{\text {Least }}+\mathrm{I}_{\text {Change }}\right) / 3 \\
= & (1+8-7) / 3=0.6=1 \\
\mathrm{~S}_{\text {Total }} & =\left(\mathrm{S}_{\text {Most }}+\mathrm{S}_{\text {Least }}+\mathrm{S}_{\text {Change }}\right) / 3 \\
= & (8+3+5) / 3=5.33=5 \\
\mathrm{C}_{\text {Total }}= & \left(\mathrm{C}_{\text {Most }}+\mathrm{C}_{\text {Least }}+\mathrm{C}_{\text {Change }}\right) / 3 \\
= & (9+4+5) / 3=6=6
\end{aligned}
$$

Langkah selanjutnya adalah mengubahnya kedalam persamaan pada tabel 4 , persamaan dapat dilihat pada tabel 3 .

Tabel 3. PERSAMAAN DISC TOTAL

\begin{tabular}{cc}
\hline \hline Range & Nilai \\
\hline-8 sampai - 7 & 1 \\
\hline-6 sampai - 5 & 2 \\
\hline-4 sampai - 3 & 3 \\
\hline-2 & 4 \\
\hline-1 sampai 2 & 5 \\
\hline 3 sampai 4 & 6 \\
\hline 5 sampai 6 & 7 \\
\hline 7 sampai 8 & 8 \\
\hline
\end{tabular}

Tabel 4. HASIL PERSAMAAN

\begin{tabular}{cc}
\hline \hline Variabel & Nilai \\
\hline $\mathrm{D}_{\text {Total }}$ & 7 \\
\hline $\mathrm{I}_{\text {Total }}$ & 7 \\
\hline $\mathrm{S}_{\text {Total }}$ & 5 \\
\hline $\mathrm{C}_{\text {Total }}$ & 5 \\
\hline
\end{tabular}

Setelah mengubah kedalam persamaan, sitem akan melakukan perhitungan profile matching, sebagai berikut:

1) Menentukan aspek dan sub aspek penilaian.

Aspek dan sub aspek yang ditentukan pada tabel 5 .

INTENSIF: Jurnal Ilmiah Penelitian dan Penerapan Teknologi Sistem Informasi 
INTENSIF, Vol.3 No.1 February 2019

ISSN: 2580-409X (Print) / 2549-6824 (Online)

Website: http://ojs.unpkediri.ac.id/index.php/intensif

Tabel 5. ASPEK DAN SUB ASPEK UNTUK POSISI KASIR DI DIVISI FINANCE ACCOUNTING

\begin{tabular}{ccccc}
\hline \hline Kompetensi & Core factor & bobot & Secondary factor & bobot \\
\hline Integrity & $\mathrm{C}$ & 7 & $\mathrm{~S}$ & 5 \\
\hline Managerial & $\mathrm{C}$ & 7 & $\mathrm{D}$ & 5 \\
\hline
\end{tabular}

2) Perhitungan pemetaan GAP

Perhitungan nilai GAP yang ditunjukan pada tabel 6

Tabel 6. PERHITUNGAN GAP POSISI KASIR DI DIVISI FINANCE ACCOUNTING

\begin{tabular}{cccc}
\hline \hline & GAP & Nilai aktual aspek - Nilai aspek yang diharapkan & Hasil \\
& & & \\
\hline Integrity & GAP1 & $7-7$ & 0 \\
\cline { 2 - 4 } & GAP2 & $7-5$ & 2 \\
\hline Managerial & GAP1 & $7-7$ & 0 \\
\cline { 2 - 4 } & GAP2 & $7-5$ & 2 \\
\hline
\end{tabular}

3) Pembobotan

Setelah diperoleh nilai GAP1 dan GAP2, maka diberikan bobot yang sudah ditentukan, berikut bobot yang ditentukan, apabila nilai dari GAP1 $>=2$ dan nilai dari GAP2 $>=-3$ maka pelamar lulus pada tahap psikotes. apabila nilai GAP1 $<1$ atau nilai GAP2 maka pelamar diwajibkan untuk mengikuti pelatihan dai kompetensi tersebut, Pada kasus ini karena nilai GAP1 >= 2 dan nilai GAP2 >= 3, maka Rayzel berhasil melewati tahap psikotes, tetapi karena nilai nilai GAP1 dari kedua kompetensi $<1$, maka Rayzel diwajibkan mengikuti pelatihan dari kompetensi integrity dan managerial.

Perancangan Manajemen Data (Database)

Perancangan manajemen data akan memberikan gambaran rancangan dari database yang digunakan untuk proses penyimpanan data. Manajemen data terdiri dari table relationship diagram dalam dilihat pada gambar 4 . 
INTENSIF, Vol.3 No.1 February 2019

ISSN: 2580-409X (Print) / 2549-6824 (Online)

Website: http://ojs.unpkediri.ac.id/index.php/intensif

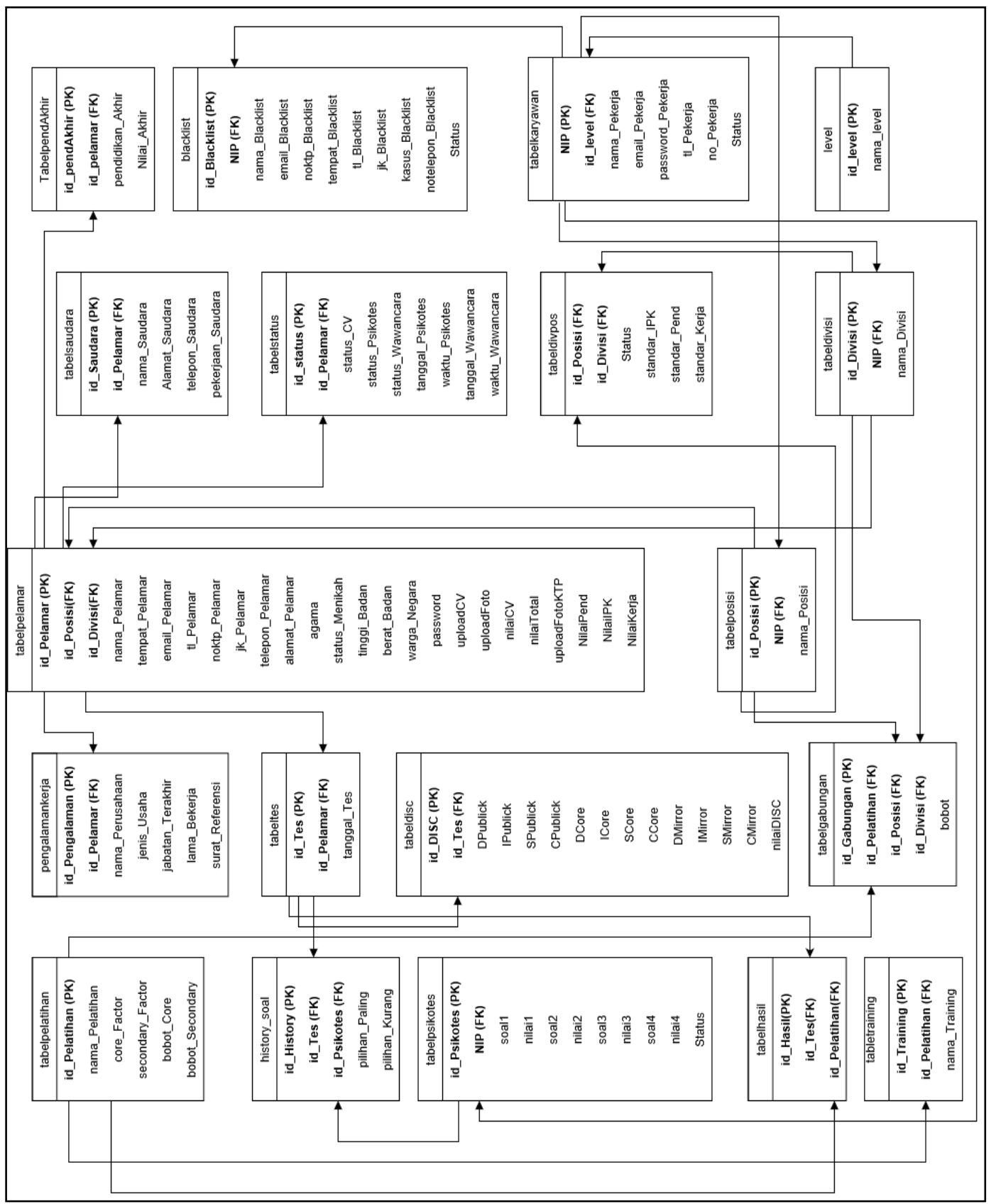

Gambar 4. TABLE RELATIONSHIP DIAGRAM : PENGEMBANGAN APLIKASI

Perancangan Lapisan Antarmuka

Pengembangan aplikasi psikotes dan alokasi pelatihan calon karyawan - pt. XYZ memiliki dua fungsi utama, yaitu fungsi untuk perekrutan dan fungsi untuk mengerjakan psikotes bagi calon karyawan. Contoh pengembangan aplikasi psikotes dan alokasi pelatihan calon karyawan - pt. XYZ dapat dilihat pada Gambar 5, Gambar 6, Gambar 7 dan Gambar 8. 
INTENSIF, Vol.3 No.1 February 2019

ISSN: 2580-409X (Print) / 2549-6824 (Online)

Website: http://ojs.unpkediri.ac.id/index.php/intensif

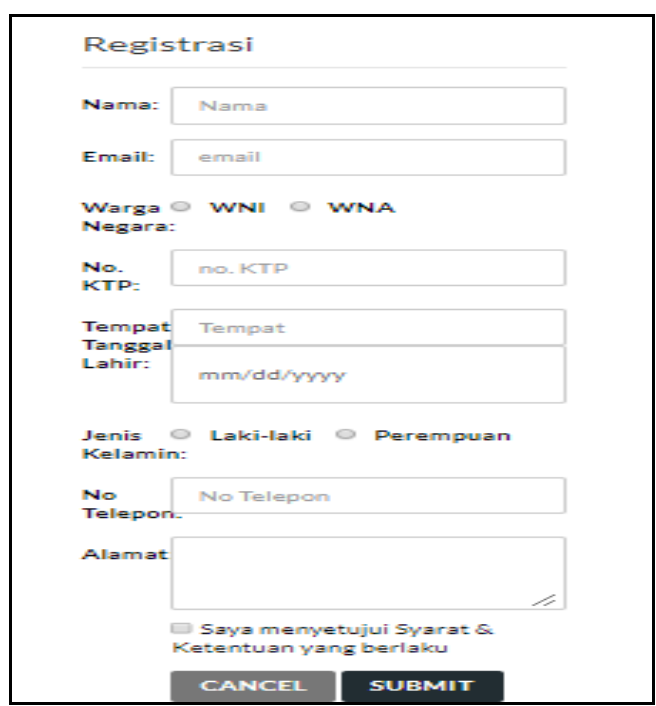

Gambar 5. HALAMAN REGISTER 1

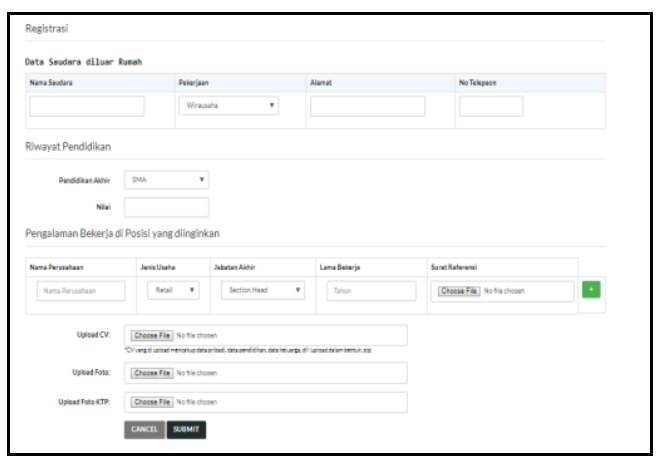

Gambar 7. HALAMAN REGISTER 3

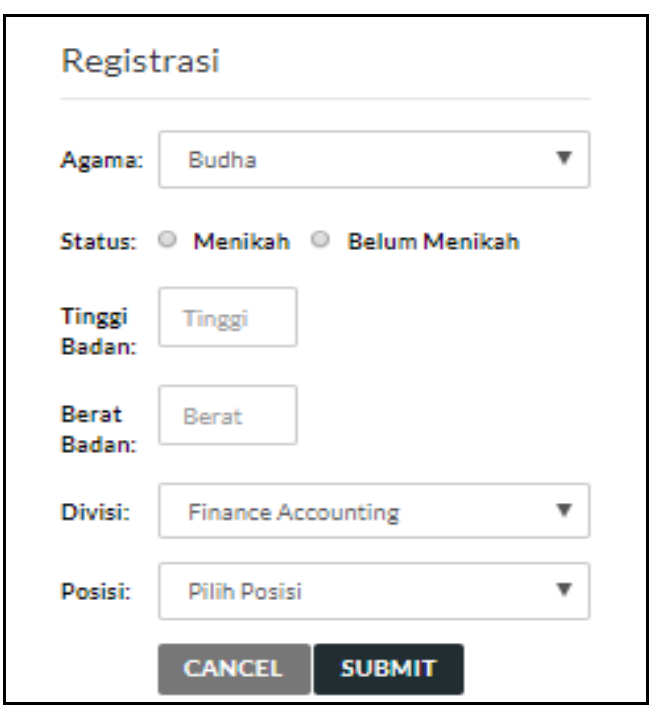

Gambar 6. HALAMAN REGISTER 2

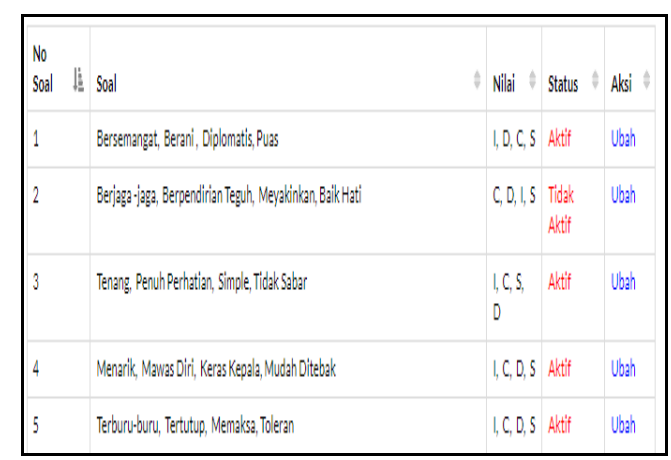

Gambar 8. MENGELOLA PSIKOTES

C. Implementasi dan Pengujian

Proses pengujian sistem informasi dibutuhkan untuk memastikan setiap fungsi yang tersedia dalam aplikasi dapat berjalan dengan baik, sehingga hasil yang dikeluarkan dapat sesuai dengan hasil yang diharapkan. Dalam tugas akhir ini, pengujian dilakukan dengan metode black-box testing.

\section{SCENARIO \#1: Melamar}

Scenario Description: skenario ini menjelaskan bagaimana pelamar melamar pekerjaan dalam sistem.

Test Script:

Skenario ini terdiri dari test script:

1. Pelamar melamar pekerjaan

\section{Use case}

1. Melamar

\section{User Group}

1. Pelamar

Script \#1.1: Pelamar melamar

Script description: test script ini menjelaskan tentang poses melamar pekerjaan yang dilakukan oleh pelamar. 
INTENSIF, Vol.3 No.1 February 2019

ISSN: 2580-409X (Print) / 2549-6824 (Online)

Website: http://ojs.unpkediri.ac.id/index.php/intensif

\section{Setup}

1. Pelamar membuka lowongan

2. Pelamar melakukan registrasi

Tabel 7 di bawah ini menunjukkan hasil pengujian yang lebih detail untuk skenario melamar pekerjaan

\section{Script Steps:}

Tabel 7. TABEL TESTING MELAMAR

\begin{tabular}{llll}
\hline \hline Step\# & Test Action & Expected Result & Status \\
\hline 1 & $\begin{array}{l}\text { Pelamar memilih } \\
\text { melamar pekerjaan }\end{array}$ & $\begin{array}{l}\text { Sistem menampilkan halaman formulir lamaran (masuk } \\
\text { dalam daftar blacklist). }\end{array}$ & Pass \\
\hline 2 & $\begin{array}{l}\text { Pelamar mengisi } \\
\text { formulir }\end{array}$ & $\begin{array}{l}\text { Sistem memeriksa data, jika data pelamar tidak sesuai } \\
\text { dengan data dari blacklist maka sistem akan menampilkan } \\
\text { halamanselanjutnya }\end{array}$ & Pass \\
\hline 3 & $\begin{array}{l}\text { Pelamar batal } \\
\text { melamar pekerjaan }\end{array}$ & Sistem kembali menampilkan halaman login. & Pass \\
\hline
\end{tabular}

IV. KESIMPULAN DAN SARAN

Pengembangan sistem informasi psikotes dan alokasi pelatihan calon karyawan pada PT.XYZ yang berfungsi membantu pihak HRD dalam melaksanakan perekrutan dan pengalokasian pelatihan calon karyawan berdasarkan hasil psikotes. Saran yang diusulkan untuk pengembangan sistem informasi psikotes dan alokasi pelatihan karyawan PT. XYZ selanjutnya adalah (1) Penambahan fitur untuk notifikasi di dalam sistem informasi, untuk memudahkan pihak HRD dalam melihat perubahan informasi terbaru. (2) Penambahan fitur untuk penjadwalan pelatihan. (4) Penambahan fitur filter untuk penanggalan pada dashboard dan pelamar.

\section{DAFTAR PUSTAKA}

[1] L. W. Santoso, A. Setiawan, and A. Handojo, Pembuatan Aplikasi Sistem Seleksi Calon Pegawai dan Pemilihan Supplier dengan Metode Analytic Network Process ( ANP ) dan Analytic Hierarchy Process ( AHP ) di PT X," Petra, vol. 9, no. 1, 2008.

[2] M. Amaliyah, dan F. Noviyanto, "Aplikasi Tes Kepribadian untuk Penempatan Karyawan Menggunakan Metode MBTI (Myers-Briggs Type Indicator) Berbasis Web (Studi Kasus : PT. Winata Putra Mandiri) “, Jurnal Sarjana Teknik Informatika, pp. 607616, vol. 1 no. 2, Oktober 2013.

[3] S. Sucipto, "Analisa Hasil Rekomendasi Pembimbing Menggunakan Multi-Attribute Dengan Metode Weighted Product ," Fountain Informatics J., vol. 2, no. 1, pp. 27-31, 2017.

[4] S. Sunarti and J. Sundari, "Perbandingan Metode SAW dan Profile Matching Pada Pemilihan Rumah Tinggal," INTENSIF, vol. 2, no. 2, pp. 115-126, 2018.

[5] A. P. Widyassari, "Aplikasi Sistem Pendukung Keputusan Penilaian Kinerja Karyawan untuk Kenaikan Gaji pada PT AAA,” INTENSIF, vol. 1, no. 2, pp. 92-101, 2017.

[6] S. Decenzo A, David and Robbins P, Fundamental of Human Resources Management, 
10th ed. United States of America: Wiley, 2010.

[7] E. Yullyanti, "Analisis Proses Rekrutmen dan Seleksi pada Kinerja Pegawai”, Jurnal Ilmu Administrasi dan Organisasi, vol. 16 no. 3, pp. 131-139, Sep-Des 2009.

[8] R. I. Desanti, C. F. Supit, and A. E. Widjaja, "Aplikasi Perekrutan dan Penilaian Karyawan Berbasis Web Pada PT . XYZ," Ultim. InfoSys, vol. VIII, no. December 2017, pp. 74-80, 2018.

[9] M. A. Sari, Siswanto, dan V. N. Sari, "Sistem Pengambilan Keputusan Penerimaan Karyawan Pada PT. Mega Auto Central Finance Cabang Manna Menggunakan Visual Basic 6.0", Jurnal Media Infotama, vol. 11 no. 1, pp. 21-30, Februari 2015.

[10] H. Purwanto, "Penerapan Metode Profile Matching dalam Sistem Pendukung Keputusan Penilaian Kinerja Karyawan Pada PT. Hyundai Mobil Indonesia Cabang Kalimalang", Jurnal Techno Nusa Mandiri, vol. xiv no. 1, pp. 15-20, Maret 2017.

[11] A. Masitoh and Suhendar, "Penerapan Metode Profile Matching Dalam Pengembangan Aplikasi E-Commerce Pada," J. Sist. Informasi, vol. 3, pp. 19-24, 2016.

[12] D. Tegarden, A. Dennis, and B. H. Wixom, Systems Analysis \& Design An ObjectOriented Approach with UML, 5th ed. USA: Wiley, 2015.

[13] A. Sofyan, P. Puspitorini, M. A. Yulianto, "Aplikasi Media Informasi Sekolah Berbasis SMS Gateway Dengan Metode SDLC (System Development Life Cycle)". Jurnal Sisfotek Global, vol. 6 no. 2, 2016.

[14] Nugroho, Hendi dan Dion Isnu Eko Nugroho. Perancangan Aplikasi Sistem Absensi Berbasis SMS Gateway, AMIKOM, Yogyakarta, 2010.

[15] B. W. Sari, "Perbandingan Metode Profile Matching dan Simple Additive Weighting Pada Penentuan Jurusan Siswa Kelas X SMAN 2 Ngaglik," DASI, vol. 16, no. 1, p. 7, 2015.

[16] S. Mufida, "Perbedaan Burn Out Ditinjau dari Gaya kepribadian Dominance, Influence, Steadiness, dan Compliance,” J. Soc. Ind. Psychol., vol. 1, no. 1, pp. 34-40, 2012. 